\section{A Tropical Perspective on Environmental Sustainability in Horticultural Education}

\author{
Kent D. Kobayashi ${ }^{1}$, Theodore J.K. Radovich, and \\ Brooke E. Moreno
}

\begin{abstract}
AdDITIONAL INDEX WORDs. organic farming, agroecology, urban agriculture, agricultural systems

Summary. Curricula in the Department of Tropical Plant and Soil Sciences at the University of Hawai'i at Mānoa were created and modified in the last few years to educate students on topics related to environmental sustainability. New programs included an Organic Food Crop Production course and the Sustainable and Organic Farm Training program. The courses Tropical Production Systems, Vegetable Crop Production, and Weed Science were modified to incorporate concepts of environmental sustainability. The new curricula and modified courses were designed to actively engage students and to promote self-learning through in-depth coverage of sustainable horticultural theory, a hands-on practicum, farm visits, and cocurricular activities. Students were exposed to a broad range of topics, including agroecology, urban agriculture, organic food production, marketing, aquaponics, and landscape ecology from a unique tropical perspective.
\end{abstract}

$\mathrm{W}$ e are seeing increasing interest in trade and popular media about the environmental degradation from agriculture. Policy makers, educators, students, and the public are concerned about the environment, food safety, and sustainable agriculture. Conventional growers have shown interest in sustainable agriculture and organic farming. At the university and institution levels, interest in organic and sustainable agriculture education has increased (Ngouajio et al., 2006).

Educational institutions are striving to address the industry's need for information, personnel, and understanding of organic and sustainable agriculture production systems (Lamb et al., 2005). Horticultural education at various universities and colleges is focusing on teaching students theory and best management practices of sustainable agriculture. To achieve this

Department of Tropical Plant and Soil Sciences, University of Hawai'i at Mānoa, 3190 Maile Way, St. John 102, Honolulu, HI 96822

We thank the students, past and present, of TPSS 200 , $300,401,481$, and 491 for their contribution to the courses. We also thank the CTAHR administration, staff, and students for their support of the SOFT program. Special thanks to Kauahi Perez and Martha Coleman for their assistance in modifying the topics and format of TPSS 300. We also gratefully acknowledge Drs. Joseph DeFrank and James Leary for their assistance with 2005 revisions to the lecture portion of TPSS 481, and Drs. Kenneth Takeda and Bernard Kratky for their input regarding revisions to TPSS 401. We appreciate Richard Criley and John Griffis' reviews of our manuscript.

${ }^{1}$ Correspnding author. E-mail: kentko@hawaii.edu. goal, horticultural education has undertaken adapting to the needs of students and consumers regarding more environmentally benign forms of crop production.

Examples of adaptation by educational institutions include the University of California, Davis, developing an undergraduate major in sustainable agriculture (Parr and Van Horn, 2006), North Carolina State University developing an interdisciplinary and multilevel approach to organic and sustainable agriculture education (Schroeder et al., 2006), Washington State University organic agriculture major, and Michigan State University developing an organic farming curriculum (Biernbaum et al., 2006). Other examples include an undergraduate interdisciplinary minor in organic and sustainable crop production (Ferguson et al., 2006), a graduate program in sustainable agriculture (Delate, 2006), and student organic farms (Biernbaum et al., 2006; Markhart, 2006).

Hawaii is an extremely isolated tropical island environment. As such, sustainability is a critical issue. At the University of Hawai'i at Mānoa
(UHM), sustainability education has encompassed the introduction of sustainability projects and curricula (Cusick, 2008). The university's goal is to become an active participant in higher education for sustainability and renewability, with the College of Tropical Agriculture and Human Resources (CTAHR) and the Department of Tropical Plant and Soil Sciences (TPSS) working together to achieve this goal. This article provides examples of how TPSS has undertaken incorporating, adapting, and integrating environmental sustainability in agriculture into the horticultural education curricula.

Personnel in CTAHR have been actively involved in research and extension activities in organic and sustainable agriculture since 1991, helping to lay the groundwork for the development of a sustainable agriculture/organic curricula. Student groups such as the Sustainable and Organic Farm Training (SOFT) organization (UHM-CTAHR, 2009) and the Horticulture Society (TPSS undergraduate organization) also helped provide input into curriculum development. CTAHR administration provides funding support for SOFT.

The rationale of the approach to incorporating sustainability into TPSS curriculum was to engage students as consumers, to address the demand for alternative approaches, and to integrate science evidence-based principles and hands on experience. In response to industry needs for experienced and trained students, hands on practicum and multiple farm visits were integrated into the curriculum. Reducing rote memory learning and increasing interactive experience-based learning and encouraging self-learning form the basis for this integration.

Sustainability is a broad concept that is specifically addressed in TPSS 200 Tropical Crop Science. The general principles of agricultural sustainability include integration of multiple tools and acknowledging and considering social and environmental costs

\begin{tabular}{lllc}
\hline $\begin{array}{l}\text { Units } \\
\begin{array}{l}\text { To convert U.S. to SI, } \\
\text { multiply by }\end{array}\end{array}$ & U.S. unit & SI unit & $\begin{array}{l}\text { To convert SI to U.S., } \\
\text { multiply by }\end{array}$ \\
\hline 0.4047 & $\mathrm{acre}(\mathrm{s})$ & $\mathrm{ha}$ & 2.4711 \\
0.3048 & $\mathrm{ft}$ & $\mathrm{m}$ & 3.2808 \\
0.0929 & $\mathrm{ft}^{2}$ & $\mathrm{~m}^{2}$ & 10.7639 \\
2.54 & inch(es) & $\mathrm{cm}$ & 0.3937
\end{tabular}


as well as economic costs of management decisions. These principles have been and continue to be incorporated into the TPSS curriculum at all levels.

\section{Creating a new course}

New courses are being developed nationwide, as well as at UHM (Cusick, 2008), to address issues of sustainability in agriculture. An example of such a course is Organic Food Crop Production (TPSS 220). This two-credit course was designed to provide a science-based overview of the ecological processes in certified organic systems (Table 1 ).

CTAHR faculty developed TPSS 220 as an introductory course that meets a basic science requirement and is open to all majors at UHM. Faculty had been successful in integrating basic principles of sustainability in foundation courses such as TPSS 200, as well as upper-division crop production courses (see examples below). However, it was felt that a separate course should address the unique aspects of certified organic production as a specific, legally defined approach toward agricultural sustainability. The course was open to university-wide enrollment, in part, to address common and extreme perceptions of organic agriculture as the sole option for agricultural sustainability or as an emotion-based fad with little practical value in commercial agriculture. The general objectives of this course are to: 1) develop in students an understanding of certified organic agricultural systems, including

Table 1. Lecture and laboratory topics covered in the course Organic Food Crop Production (TPSS 220) at University of Hawai'i at Mānoa.

Organic overview, ecology, history, and current status

Transplanting

Soil health and fertility

Organic amendments and soil builders

Compost tea and soluble fertilizers

Pest control

Weed management strategies

Organic pesticides

Organic taro

Vermicompost production

Organic weed trial harvest

Environmental influence on crop quality

Cost of production and marketing

Sensory evaluation

Legume nodulation trial

Agricultural biotechnology the challenges associated with making them sustainable, and how they differ from other systems designed to improve agricultural sustainability; 2) to engage students in hands-on learning of strategies designed to maximize the efficacy of biological cycles within the farm and garden to optimize the economic, environmental, and social sustainability of the food production system; and 3) to facilitate the development of independent research, thought, and problem-solving processes with regard to organic food crop production.

Students acquire hands-on experience in organic vegetable production and experimentation and participate in field trips to observe the commercial aspects of organic vegetable production, and in student garden projects. Independent and group research projects demonstrate the application of science in improving our understanding of biological cycles in organic agriculture (Fig. 1) (Pant et al., 2009). Also, particular importance is placed on field trips to working farms (Fig. 2). A unique combination of constraints in Hawaii includes year-round pest pressure, high input and labor costs due to the high cost of living, and stringent environmental regulations to protect native flora and fauna. These can be especially challenging for organic farmers. Direct engagement with organic producers provides students a realistic view of challenges and opportunities in tropical organic agriculture. Emphasized in the course are what is involved in organic certification and agricultural biotechnology which entails, in part, that molecular biology has potential value to organic agriculture (e.g., the development of molecular markers for disease resistance). The topic of legume nodulation trial covers organic nitrogen sources and legume nodulation.

Examples of assignments and activities given to students to meet the objectives include: 1) interaction of inoculation and soil type on growth of leguminous groundcovers, 2) grant proposal development, and 3 ) interactive online mapping of various direct marketing outlets for organic farmers. Course enrollment was 12 students in the first year, 18 in the second year, and 24 students in the third year.

\section{Modifying current courses}

Although it is appropriate to develop new courses to address issues of sustainability when needed, perhaps one of the most important changes to changing curricula at land grant institutions is the incorporation of concepts of sustainability into core courses that have been taught for many years. A common approach is to emphasize horticultural production systems as intensively managed ecosystems and to present management practices within an ecological

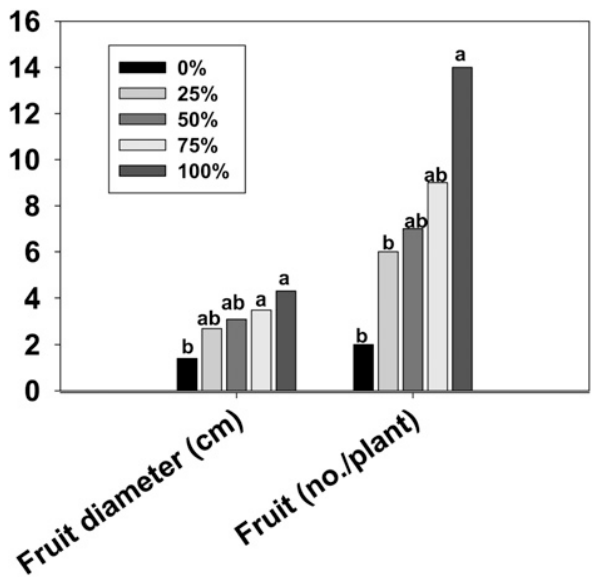

Fig. 1. A vermicompost fertilization experiment with organically grown 'Kewalo' tomato seedlings was conducted by students in TPSS 220 Organic Food Crop Production. The five treatments were a commercial peat-based medium without any supplemental vermicompost fertilization $(0 \%)$ and media with $25 \%, 50 \%, 75 \%$, or $100 \%$ of the peat mix replaced with vermicompost. Values of fruit diameter and fruit number are means of six plants per treatment $60 \mathrm{~d}$ after transplanting. Means with the same letter were not significantly different from each other $(\alpha=0.05) ; 1 \mathrm{~cm}=$ 0.3937 inch. 


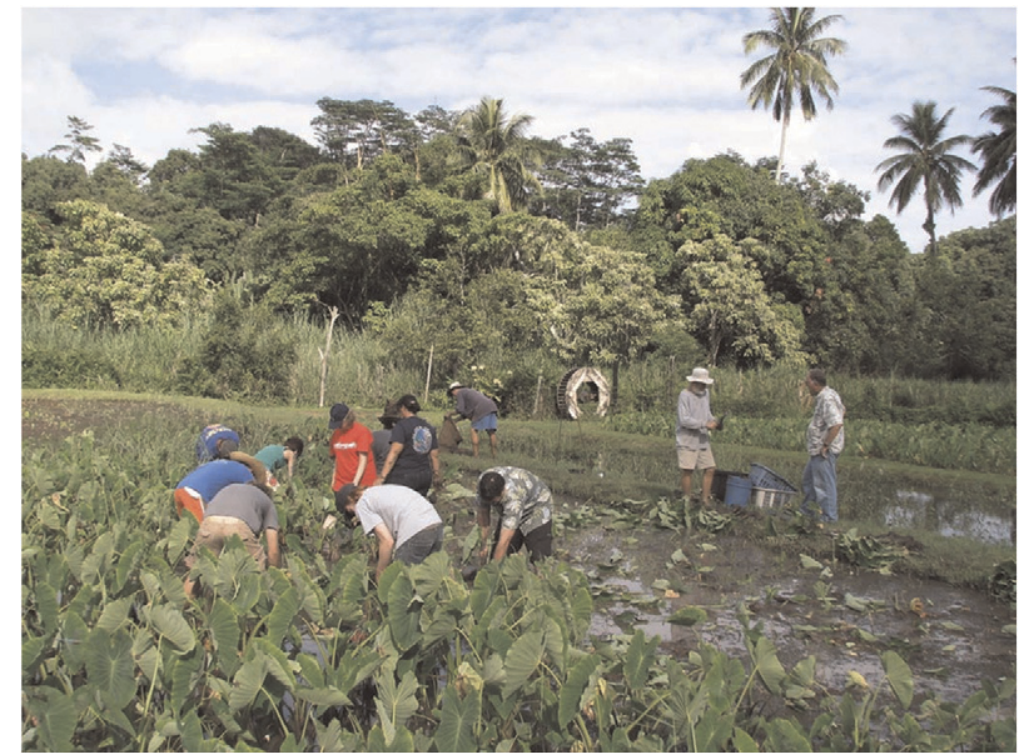

Fig. 2. Students in TPSS 220 Organic Food Crop Production learning principles of harvesting taro on a farm in Waiahole, $\mathrm{HI}$.

context (Zimdahl, 2007). Three examples, among many courses within CTAHR in which this has occurred are Tropical Production Systems (TPSS 300), Vegetable Crop Production (TPSS 401 ), and Weed Science (TPSS 481).

Tropical Production Systems (TPSS 300). TPSS 300 serves as a bridge between the introductory course TPSS 200 and the upper division production courses in vegetables, tropical fruit, flowers, and foliage crops. The objectives of this course are to teach students about different crop production systems and crop management systems; how environmental factors and crop manipulation influence crop growth and development in different production systems; and how to identify problems in production and apply an organized approach to their solution.

Previously, TPSS 300 had covered a broad range of 41 topics with only a few topics about sustainability, including water environmental concerns, integrated pest management (IPM), weed control IPM/living mulches, and federal standards for organic food production (University of Hawai'i at Mānoa, Department of Tropical Plant and Soil Sciences, 2004a). In the last 3 years, TPSS 300 has been modified to incorporate more topics on environmental sustainability in agriculture (Kobayashi and Perez, 2009). New topics that were added include sustainable agriculture, agroecology, aquaponics, precision agriculture, urban agriculture, forest gardening, landscape ecology, green roofs, vertical farming, and space farming (Table 2). Where appropriate, organic farming principles are briefly covered under the various topics.

TPSS 300 is organized to help students see agricultural enterprises as sustainable systems. Emphasis is placed on critical thinking skills, problem solving, decision-making, communication skills, and active learning (Monteiro, 2007). Comparisons are made between traditional agricultural systems and more sustainable systems. Systems analysis is used to help students evaluate different production systems and make decisions regarding best management practices. Sustainability concepts are covered as broad topics such as sustainable agriculture and agroecology and then are further ent production systems such as field crops, controlled environments, aquaponics, hydroponics, and green roofs.

A new activity is the use of virtual field trips in which each student visits an agricultural enterprise and interviews the owner/manger in person to learn about the production system and the sustainable agriculture practices used (Kobayashi and Perez, 2010). Each student then develops a multimedia presentation that simulates an actual field trip to the agricultural enterprise, and presents it to the class. emphasized and applied in the differ-
Table 2. Lecture and laboratory topics covered in the course Tropical Production Systems (TPSS 300) at University of Hawai'i at Mānoa.

Systems analysis

Production systems

Environmental factors

Environmental monitoring

Field agriculture

Irrigation

Cropping systems

Controlled environment agriculture

Tissue culture

Sustainable agriculture

Agroecology

Aquaponics, hydroponics

Precision agriculture

Pruning

Crop scheduling

Urban agriculture

Forest gardening, landscape ecology

Green roofs, container gardening

Mechanization

Future technology, space farming, and vertical farming

VEGETABLE CROP PRODUCTION (TPSS 401). This course develops student understanding of the biological, social, and economic principles underlying successful vegetable production. Previous topics included seedlings and transplants, pests, irrigation, hydroponics, fertilization, greenhouses, rain shelters, plasticulture, harvesting, and marketing (University of Hawai'i at Mānoa, Department of Tropical Plant and Soil Sciences, 2004b). Recently, instructors who have previously taught this class collaborated with new faculty to increase the emphasis on vegetable production systems as ecosystems with integrated function. To achieve this, the first several lectures introduce the socioeconomic and environmental components of tropical vegetable agroecosystems (Table 3). The topics covered in these introductory lectures provide the ecological context for the production practices discussed throughout the course and include origin, domestication, and improvement of vegetables; the importance of vegetables to the human diet; environmental factors influencing vegetable growth; and sustainability in agriculture.

Commercial production practices for all major vegetable families are covered, with a special emphasis on species and varieties relevant to the 
tropics. Also covered are tropical sources of starch including sweetpotato (Ipomoea batatas), taro (Colocasia esculenta), cassava (Manibot esculenta), plantain (Musa xparadisiaca), and breadfruit (Artocarpus altilis). Many of these are considered "minor" crops in the mainland, temperate United States, but are essential to the food security of much of the tropics. The laboratory component of this class includes multiple field trips to conventional, integrated, and organic farms, as well as visits to wholesale warehouses, local agrichemical and vegetable seed distributors, and composting facilities. Locally available resources and markets are highlighted.

WeED SCIENCE (TPSS 481). The course objectives are to understand what weeds are, why they are important, and how they interact with their environment, and to develop the ability to design weed management strategies for different systems by integrating an understanding of weed-crop interactions with knowledge of a wide range of control measures. Because of the importance of herbicides in controlling weeds in horticulture, it is appropriate to place a strong focus on chemistry in introductory weed science curricula. The presentation of weed ecology as peripheral to weed science, however, can result in the exclusion or trivialization of important non-chemical control measures and their practical application to basic weed management (Monaco et al., 2002; Zimdahl, 2007). In addition, the increase in petroleum prices and the decline in petroleum stocks require that alternatives to petroleumbased herbicides be explored.

TPSS 481 has historically put strong emphasis on weed ecology, and laboratory activities have included scientific evaluations of allelopathy, living mulches, and other cultural and mechanical control measures (DeFrank, 2007). The lecture portion of the course was revised in 2005 into three sections: 1) biology, physiology, and ecology of weeds (five lectures); 2 ) control measures (13 lectures); and 3 ) integrated weed management in agricultural systems (eight lectures) (Table 4). The overall goal of organizing the lectures into three sections, as described above, was to develop in students the ability to design weed management strategies for a wide range of systems (including certified organic) by integrating an understanding

Table 3. Lecture and laboratory topics covered in the course Vegetable Crop Production (TPSS 401) University of Hawai'i at Mānoa.

Vegetable definition and classification

Origin, domestication, and improvement of vegetables

Importance of vegetables to the human diet

Environmental factors influencing vegetable growth

Sustainability in agriculture

Seeding transplants

Nutrient management and irrigation

Pest (including weed) management and pesticide safety

Marketing and postharvest handling

Potato (Solanum tuberosum), sweetpotato (Ipomoea batatas), taro (Colocasia esculenta), other aroids, cassava (Manihot esculenta), plantain (Musa ×paradisiaca), breadfruit (Artocarpus altilis), sweet corn (Zea mays), tomato (Solanum lycopersicum), pepper (Capsicum spp.), eggplant (Solanum melongena), other Solanum fruit, lettuce (Lactuca sativa), other Asteraceae, onion (Allium cepa), other Allium spp., Cucurbitaceae, Brassicaceae, carrot (Daucus carota), other Apiaceae, spinach (Spinacea oleracea), beet (Beta vulgaris), other Chenopodaceae, and other vegetables

Experimental design

Table 4. Lecture and laboratory topics covered in the course Weed Science (TPSS 481) at University of Hawai'i at Mānoa.

Introduction to weeds and their importance

Weed ecology

Weed reproduction

Introduction to integrated pest management (IPM)

Control measures: cultural practices

Mechanical and physical control

Biological control

Introduction to herbicides and their importance

Herbicides: labeling, regulation, and environmental impact

Herbicide formulation and application

Herbicide behavior in plants

Herbicide chemistry and classification

Herbicide modes of action

Herbicide behavior in soils

Natural and engineered resistance to herbicides

Integrated weed management in systems: field crops, vegetables, orchards, certified organic systems, turf, landscape crops, nursery crops, pasture, rangelands, forests, natural systems (dryland), wetlands, and riparian areas

of weed-crop interactions with indepth knowledge of a wide range of control measures. Significant lecture time in section 2 was devoted to providing tropical examples of non-chemical control measures and the ecophysiological basis of their efficacy as supported by refereed journal articles (e.g., Khahn et al., 2006; Leary et al., 2006; Wang et al., 2008).

Sustainability is discussed within specific context of each class because students do not take all classes. Faculty specializing in agricultural sustainability guest lecture in nearly all TPSS production-oriented classes to provide continuity across programs. There have been discussions but no definite plans to add additional courses to the TPSS program in the future.

\section{Cocurricular activities}

Student initiatives and interest in sustainable agriculture education currently include vibrant extracurricular activities and will continue to be crucial in creating change on campuses. Student farms have a well-established history at many universities, and more new student farms continue to be developed (Biernbaum et al., 2006; Markhart, 2006).

Started in 2007, SOFT is a student-managed farm program funded by CTAHR (UHM-CTAHR, 2009). SOFT members, who chose the name, 
include undergraduates, graduate students, faculty, and community members interested in sustainable and organic farming practices. Students developed SOFT to take an active role in their education while also creating a physical place to put theory into practice. The main operation is a 1 acre organic farm located on a CTAHR experiment station in Waimānalo, HI. Through this farm, a community of people interested in sustainable agriculture, local food, and gardening has developed. About 11 CTAHR faculty are involved in helping to advise the students in the operation of the farm.

SOFT members have been invited to present talks in agriculture, environmental management, and political science courses where issues of sustainability and local food are discussed. SOFT provides students a venue to incorporate ideas they have learned and turn it into actions that create positive change in the campus community and help improve the practicality of their education.

To facilitate integration of the student-run farm with the TPSS Department, SOFT initiated student involvement as part of laboratory requirements of UHM courses, including TPSS 300 and Fruit Crop Production (TPSS 403). TPSS 300 students assisted with setting up a rooftop hydroponic system in which experimentation with different organic hydroponic solutions will continue to be part of student research. TPSS 403 students assisted in the research, development, and planting of a fruit tree orchard at the main SOFT farm site.

SOFT members grow food to help ensure a sustainable vegetable supply for the UHM campus. This is accomplished through three agricultural operations: an organic farm in Waimanalo, $\mathrm{HI}$, a vegetable farm at a CTAHR greenhouse facility, and rooftop hydroponic systems on campus. Numerous varieties of fruit trees, plants, and shrubs, including 21 varieties of banana (Musa spp.), avocado (Persea americana), jaboticaba (Myriciaria cauliflora), starfruit (Averrboa carambola), and guava (Psidium guajava), and an herb garden are grown. The farm is currently not certified organic, but students plan to work toward certification. Students pay user fees to CTAHR, and land and machinery are provided to the students for the operation of the farm. This farm offers the opportunity

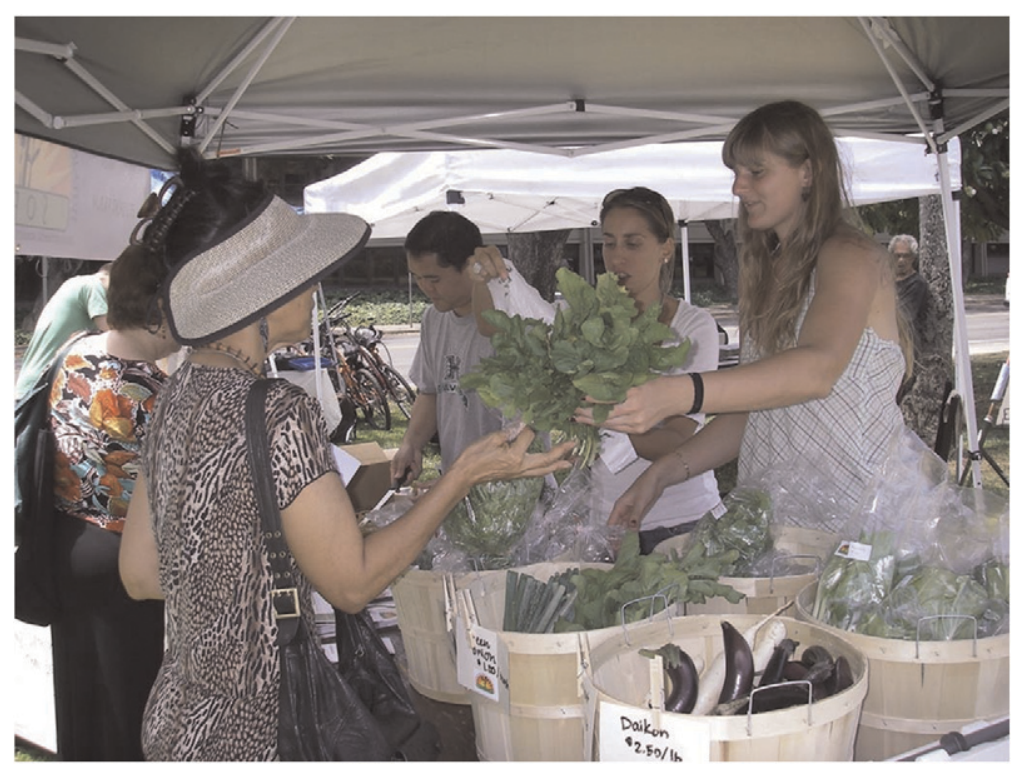

Fig. 3. Sustainable and Organic Farm Training (SOFT) students selling produce on the University of Hawai'i at Mānoa campus from their three agricultural operations: a 1 -acre $(0.4 \mathrm{ha})$ organic farm, a vegetable farm on campus, and noncirculating and nutrient film technique hydroponic systems on campus. SOFT is a student-managed farm program whose members include undergraduates, graduate students, faculty, and community members interested in sustainable and organic farming practices.

for creative experimentation, such as using salvaged cardboard and coffee bags as alternative mulch, and a future site to explore permaculture and agroforestry principles in food production.

The second operation is a vegetable farm at the CTAHR Magoon Greenhouse Facility on campus where vegetables are produced on $1500 \mathrm{ft}^{2}$, which will increase in size to nearly one-half acre in the future. The third operation includes outdoor noncirculating and nutrient film technique hydroponic systems for lettuce (Lactuca sativa) and tomato (Solanum lycopersicum) production on the south side of the sixth floor of a building on campus, with cucumber ( $\mathrm{Cucu}$ mis satious) planned for the near future. Both hydroponic systems are oriented east to west and receive $\approx 9$ to $11 \mathrm{~h}$ of sunlight per day, depending on the season. The two $3.3 \times 8 \mathrm{ft}$ noncirculating hydroponic tanks produce a total of 84 heads of lettuce. The $5 \times$ $10.7 \mathrm{ft}$ nutrient film technique hydroponic system can produce 75 heads of lettuce. Produce from these three operations are sold on campus to help support farm operations.

Through sales, students are able to connect with their customers, thus learning about marketing (Fig. 3). This helps create a campus network of faculty and students who are aware of the student farm and become supporters of it. Students are working hard with faculty and staff to establish a new community and tool for experiential learning. The flexibility built into the student farm allows students to incorporate their own interests and conduct research on the farm. Student-led research includes using cardboard and coffee bags as alternative mulch and architectural diversity in food production systems.

Creation of new courses, modification of several current courses, and establishment of the SOFT program are examples of efforts aimed to address the interests and needs of our students on topics related to environmental sustainability in TPSS. Our horticultural education curricula are adapting to provide a new generation of students with horticultural theory, a hands-on practicum, farm visits, and cocurricular activities. Through these efforts, we hope to foster a strong, pragmatic enthusiasm for sustainable horticulture in the tropics.

\section{Literature cited}

Biernbaum, J.A., L. Thorp, and M. Ngouajio. 2006. Development of a yearround student organic farm and organic 
farming curriculum at Michigan State University. HortTechnology 16:432-436.

Cusick, J. 2008. Operationalizing sustainability education at the University of Hawai'i at Mānoa. Int. J. Sustain. High. Educ. 9:246-256.

DeFrank, J. 2007. Lecture notes and handouts for weed science lab (TPSS/ PEPS 481-Fall 2007). 18 June 2009. $<$ http://www2.hawaii.edu/ defrenk $>$.

Delate, K. 2006. Incorporating organic and agroecological approaches into the university curricula: The Iowa State University graduate program in sustainable agriculture. HortTechnology 16:445-448.

Ferguson, J.J., E. Lamb, and M. Swisher. 2006. Developing an interdisciplinary organic and sustainable agriculture curriculum at the University of Florida. HortTechnology 16:436-438.

Khahn, T.D., I.M. Chung, S. Tawat, and T.D. Xuan. 2006. Weed suppression by Passiflora edulis and its potential allelochemicals. European Weed Res. Soc. 46:296-303.

Kobayashi, K. and K. Perez. 2009. Enhanced active learning and TA involvement in a production systems horticulture course. 2009 Hawaii Intl. Conf. Educ.Conf. Proc. 738-748.

Kobayashi, K.D. and K. Perez. 2010. Could horticultural virtual field trips supplement actual field trips? 2010 Hawaii Intl. Conf. Educ.-Conf. Proc. 29342946.
Lamb, E., R. Darnell, C. Hutchinson, E. Simonne, and M. Webb. 2005. Integrating organic and sustainable agriculture into a horticultural science curriculum. Acta Hort. 672:197-203.

Leary, J.K., J. DeFrank, and B. Sipes. 2006. Tropical eggplant (Solanum melongena L.) production with a buffelgrass (Pennisetum ciliare L.) living mulch system in Hawaii. Biol. Agr. Hort. 24:105-116.

Markhart, A.H., III. 2006. Organic educational opportunities at the University of Minnesota: The role of a student-run organic farm. HortTechnology 16:443-445.

Monaco, T.J., S.C. Weller, and F.M. Ashton. 2002. Weed science: Principles and practices, 4th ed. Wiley, New York.

Monteiro, A.A. 2007. Education for sustainable horticulture. Acta Hort. 762: 407-415.

Ngouajio, M., K. Delate, E. Carey, A.N. Azareno, J.J. Ferguson, and W.J. Sciarappa. 2006. Curriculum development for organic horticulture: Introduction. HortTechnology 16:414-417.

Pant, A., T.J.K. Radovich, N.V. Hue, S.T. Talcott, and K.A. Krenek. 2009. Compost extracts influence growth, total carotenoids, phenolics and antioxidant activity in pak choi (Brassica rapa chinensis group) grown under two fertilizer regimes. J. Sci. Food Agr. (in press)

Parr, D.M. and M. Van Horn. 2006. Development of organic and sustainable agricultural education at the University of
California, Davis: A closer look at practice and theory. HortTechnology 16:426-431.

Schroeder, M.S., N.G. Creamer, H.M. Linker, J.P. Mueller, and P. Rzewnicki. 2006. Interdisciplinary and multilevel approach to organic and sustainable agriculture education at North Carolina State University. HortTechnology 16:418-428.

University of Hawai'i at Mānoa, College of Tropical Agriculture and Human Resources. 2009. SOFT: Sustainable and organic farm training. 25 May 2009. <http://www.ctahr.hawaii.edu/organic/ SOFT.asp $>$.

University of Hawai'i at Mānoa, Department of Tropical Plant and Soil Sciences. 2004a. Tropical production systems TPSS 300. 18 Jan. 2010. <http://www.ctahr. hawaii.edu/ctahr2001/TPSS/academics/ courses/undergrad/tpss300/tpss300. html>.

University of Hawai'i at Mānoa, Department of Tropical Plant and Soil Sciences. 2004b. Vegetable crop production TPSS 401. 20 Jan. 2010. <http://www.ctahr. hawaii.edu/ctahr2001/TPSS/academics/ courses/undergrad/tpss401/tpss401. html>.

Wang, K.H., R. McSorely, R.N. Gallaher, and N. Kokalis-Burelle. 2008. Cover crops and organic mulches for nematode, weed and plant health management. Nematology 10:231-242.

Zimdahl, R.L. 2007. Fundamentals of weed science, 3rd ed. Elsevier, Burlington, MA. 